\title{
BUDAYA LOKAL DAN OTONOMI DAERAH DALAM KAITANNYA DENGAN KEISTIMEWAAN YOGYAKARTA
}

\author{
Jawahir Thontorvi*
}

\section{Abstract}

The Act No. 22, 1999 on region autonomy has raised or appeared a problem for the special territory of Yogyakarta, especially in relation with the leadership system regulation authority and possession of land. It happened when the principle of equality before the law and political rights of society were not accommodated well in the democratic concept reference. So, the harmonization between social realities of local society of Yogyakarta with the universal demand of democracy must be connected. Harmonization in this contexts means as an effort to explain some possibilities of how the effort takes a place when there is not adjustment between both demand of local value in reformation era and the democratic value. The wish to force one system without paying attention to another, cause the social dynamic will not grow well and the conducive society situation will not happen.

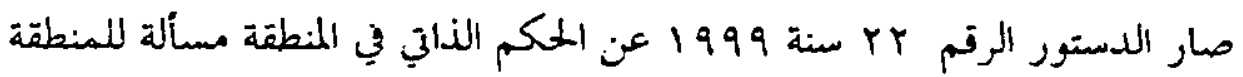

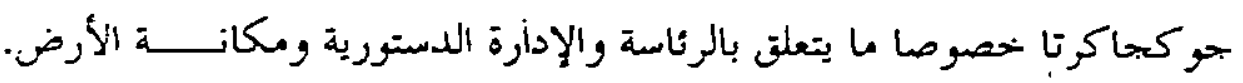

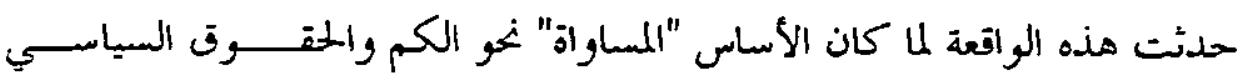
للمعتمع لم تكن. مضمونة عند الفكرة اللديمقراطية. لنفا لابد للتناسق بين الواقعسية الإجتماعية في المحتمع بيو كجاكرتا والطلب الكلي للندمقراطية أن يكونا متصلين. إن التناست في هذه العلاقة عمعن المسعي ليبين الاحتمالات عن كيف كان اللمسعي

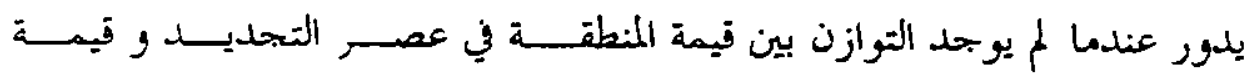

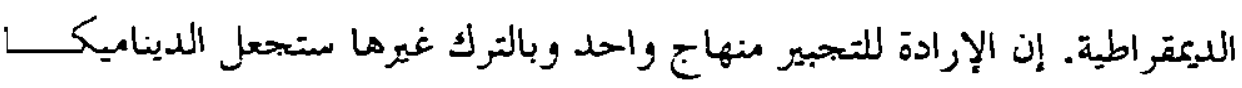
الإجتماعي لا ينبت جيدا. 


\section{A. Pendahuluan}

Judul di atas bukan sekedar menggambarkan persoalan identitas keistimewaan DIY itu identik dengan diskriminasi dalam kehidupan demokrasi, melainkan bagaimana sebenarnya masyarakat Yogyakarta mengakui sistem kepemimpinan lokal itu pantas, adil dan sesuai dengan parameter hukum. Kehadiran UndangUndang No. 22/1999 mengenai otonomi daerah tampak tidak sekedar dapat dijadikan payung hukum dalam membedah sistem kekuasaan yang selama ini sangat sentralistik, melainkan bagaimana pula semangat desentralisasi tidak merusak bentuk negara kesatuan Republik Indonesia (NKRI) dan juga nilainilai budaya lokal. Penerapan sistem politik yang demokratis bukan sekali untuk selamanya, melainkan perlu ada proses sejarah dan kesadaran yang perlu terus diupayakan dan diperbaiki secara konstan dan konsisten.

Karena itu, lahimya UU No. 22/1999 bagi Daerah Istimewa Yogyakarta, khususnya dalam kaitannya dengan kepemimpinan dan pengaturan sistem penguasaan serta pemilikan tanah menjadi persoalan yang sangat penting, terutama ketika prinsip kesederajatan dalam hukum dan hak-hak politik bagi masyarakat tidak selalu dapat diakomodasikan sepenuhnya ke dalam acuan konseptual demokratis. Atas dasar itu, harmonisasi realitas sosial masyarakat lokal Yogyakarta dengan tuntutan universal demokrasi perlu dijembatani. Harmonisasi dalam konteks ini dimaksudkan sebagai suatu usaha menjelaskan berbagai kemungkinan bagaimana upaya yang harus dikedepankan bilamana kedua tuntutan nilai lokal dengan era reformasi dan nilai-nilai demokrasi terdapat ketidaksesuaian. Hasrat untuk memaksakan salah satu sistem tanpa mempertimbangkan nilai-nilai lokal yang cukup cermat boleh jadi dinamika sosial yang tumbuh tidak akan membuahkan hasil dan situasi masyarakat yang kondusif.

Untuk menjelaskan urgensi eksistensi harmonisasi tersebut persoalan penting perlu dikemukakan yaitu mengapa secara historis model kepemimpinan di Yogyakarta dikelompokan ke dalam Daerah Istimewa? Bagaimana pula parameter sosiologis dan yuridis dapat menjadi landasan bagi tegaknya kepemimpinan Yogyakarta di mana Sultan dan Paku Alam memiliki hak untuk menjadi kepala dan wakil kepala Daerah Tingkat I Propinsi? Selain itu, pertanyaan yang perlu dikemukakan: Apakah penggunaan istilah "Istimewa" identik dengan diskriminasi dalam nuansa kehidupan negara yang demokratis? Dan usaha apakah yang harus dilakukan agar hak keistimewaan (penguasaan atas tanah dan jabatan gubernur hanya terpusat kepada keturunan Raja atau Sultan) tidak bertentangan dengan tuntutan demokrasi ?

\section{B.DIY dalam Pertumbuhan Sistem Hukum Indonesia}

Dalam negara yang sedang berkembang, usaha unifikasi dan kodifikasi hukum tertulis tidak selalu dapat berjalan dan diterima sepenuhnya oleh 
masyarakat dengan mulus. Faktor di luar sistem hukum, misalnya faktor budaya, terkadang turut menentukan proses bagaimana suatu peraturan hukum dapat dipatuhi secara seksama. Salah seorang filosof Jerman seperti Eigen Ehrlich mengasumsikan bahwa pembentukan peraturan hukum sebenarnya berjalan seiring dengan perkembangan masyarakat. Pada saat suatu masyarakat telah memiliki organisasi yang secara politis legitimate, maka peraturan hukum umumnya diakui jika dikeluarkan oleh lembaga legislatif. Namun, dalam realitas sosial sebenarnya, hukum yang hidup (living law) dalam masyarakat tidak selalu terakomodasikan ke dalam peraturan hukum tertulis. Ehrlich menegaskan bahwa "saat ini dan juga masa lalu, pusat daya tarik perkembangan hukum menyadarkan dirinya tidak sekedar pada undangundang, teori hukum, putusan pengadilan, melainkan lebih ditentukan oleh

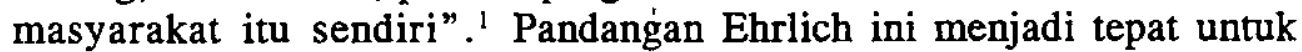
dipergunakan terutama ketika eksistensi Sultan dalam proses kepemimpinan dan demokratisasi dikaitkan dengan makna Otonomi Daerah.

Pandangan tersebut dianggap relevan untuk dikaitkan dengan semangat desentralisasi, khususnya dengan lahirnya UU No 22/1999 tentang Otonomi Daerah. Berdasarkan kepada konsideransinya atas undang-undang tersebut, kekhususan Yogyakarta untuk beberapa saat tampaknya dapat ditolelir.

Berdasarkan petunjuk di atas, masalah budaya hukum merupakan salah satu agenda reformasi hukum yang harus segera ditangani dan digarap secara seríus, di samping aspek-aspek hukum lainnya. Pengalaman masa lalu bangsa Indonesia yang hanya menekankan aspek yuridis formal, tanpa menekankan pada pembangunan perilaku hukum dan moralitas hukum masyarakat, bangsa Indonesia telah jatuh ke dalam kesalahan-kesalahan yang serius. Dengan demikian pengkajian tentang budaya hukum menjadi hal yang penting dan relevan terutama berkaitan dengan pengkajian hukum empiris.

Dasar filosofis lahirnya UU Otonomi Daerah salah satunya adalah sebagai usaha menghindari pemusatan kekuasaan pemerintah di Pusat. Karena itu, secara umum ketentuan otonomi daerah tersebut tidak lain sebagai usaha pemberdayaan pemerintah daerah dalam penyelenggaraan pemerintah daerah yang otonom.

Eksistensi daerah otonom tersebut hanya dapat dilaksanakan bilamana menganut asas desentralisasi. Suatu asas penyerahan wewenang pemerintah oieh pemerintah pusat kepada daerah otonom. Sebagaimana ketentuan pasal 1 (d,h dan $\mathrm{f}$ ), hal itu berarti Yogyakarta merupakan satu kesatuan hukum

\footnotetext{
' Pandangan Ehrlich ini dikembangkan oleh Stewart Maculay dalam penelitiannya, dengan bukti bahwa kaum bisnismen di Amerika cenderung menggunakan model praktek pembikinan kontrak di ltuar ketentuan hukum tertulis. Lihat Cotterel, The Sociology of Law, 1984, Butterworths, London, hal. 35. Bandingkan pula dengan Alan Watson. Society and legal Change, 1997, Scotish Academic Press, Edinburg, hal.131.
} 
yang mempunyai batas tertentu berwewenang mengatur dan mengurus kepentingan masyarakat setempat menurut prakarsa sendiri berdasarkan aspirasi masyarakat dalam ikatan NKRI. Dengan hal lain, otonomi daerah, kewenangan daerah otonom untuk mengatur segala kepentingan masyarakat berdasarkan aspirasi dan didasarkan kepada ketentuan perundang-undangan.

Bilamana memperhatikan ketentuan di atas, jelasiah bahwa otonomi daerah bagi DIY bukan merupakan persoalan yang sama sekali baru. Pertama, secara faktual kabupaten Kota Kasultanan dan Kabupaten Kota Pakualaman telah dibentuk satu wilayah Kota, yang kemudian pada perlembagaan berikutnya menjadi Propinsi DIY. Dasar hukumnya yaitu Maklumat No 18/1946 dan diperkuat dengan lahirnya UU RI No 16/1950.

Konsekuensi dari kehadiran UU tersebut adalah, tidak ada alasan bagi pemerintah pusat untuk tidak memberikan wewenang kepada DTY sebagai daerah otonom. Selo Soemardjan menegaskan bahwa kata otonom sudah ada sejak dahulu, maka kekuasaan otonomi yang diperoleh Kota Praja Yogyakarta, secara de jure sejak tahun 1947 dan secara de facto sejak tahun 1951, yang merupakan salah satu hasil revolusi. ${ }^{2}$ UU No 18/1965 UU Pokok Pemerintah Daerah tegas mengatur dalam Pasal 88 Peraturan Peralihannya.

1. Pada saat mulai berlakunya Undang-undang ini, maka:

Daerah Tingkat I dan Daerah Istimewa Yogyakarta yang berhak mengatur dan mengurus rumah tangganya sendiri berdasarkan Undang-Undang No.

1 Tahun 1957 serta Daerah Istimewa Aceh berdasarkan Keputusan Perdana Menteri RI No. 1 MISSI/1959 adalah propinsi termaksud pada pasal 2 ayat (1).

Sifat Istimewa suatu Daerah yang berdasarkan atas ketentuan mengingat kedudukian dan hak-hak asal usul dalam Pasal 18 UUD yang masih diakui dan berlaku hingga sekarang atas sebutan Daerah Istimewa atas alasan lama, berlaku terus hingga dihapuskan. ${ }^{3}$

Tarik menarik antara aspirasi lokal dan nasional dalam bingkai hukum dan kepemimpinan tampak menjadi jauh lebih positif dan konstruktif, khususnya dalam mengakomodasikan aspirasi lokal, termasuk model kepemimpinan. Oleh karena itu, tarik menarik antara hukum dan kekuasaan (modern dan tradisional) acapkali tidak bisa dihindarkan, meskipun dalam teorinya suatu negara telah menganut model pembagian (distribution of power) dan pemisahan kekuasaan (separation of power). Begitu pula suatu sistem hukum dan penegakannya sangat tergantung kepada berbagai faktor, baik faktor internal hukum (hukum material dan formal) itu sendiri maupun faktor eksternal (sosial, politik, dan stabilitas). Dengan kata lain, peranan

- Selo Soemardjan, 1991, Perubahan Sosial di Yogyakarta, Gadjah Mada Press, Yogyakara, hal. 178.

"Soedarisman Poenwokoemo, 1979, Daerah Istemewa Yogyakarta, Gadjah Mada Piess, Yogyakara, hal. 28. 
kepemimpinan sebagai bagian dari mekanisme kekuasaan selain ditentukan oleh peraturan hukum, juga nilai budaya suatu tempat. Tidak berlebihan jika konsiderasi UU No. $22 / 1999$ bisa dipergunakan sebagai salah satu acuan dasar perlunya harmonisasi. Dalam konsiderasinya ditegaskan bahwa dalam penyelenggaraan otonomi daerah, dipandang perlu lebih menekankan pada prinsip demokrasi, peran serta masyarakat, pemerataan dan keadilan, serta memperhatikan potensi dan keanekaragaman daerah.

Sistem hukum dalam suatu masyarakat bukan saja terdiri dari hukum substantif (peraturan hukum material, baik tertulis maupun tidak tertulis), dan prosedural (proses bagaimana suatu kasus diselesaikan di pengadilan atau lembaga non-peradilan), melainkan juga bagaimana budaya hukum masyarakat (lokal atau nasional, global) dapat menjadi faktor pendorong atau penghambat dalam seluruh proses penegakan hukum. "Budaya hukum adalah sekumpulan kebiasaan-kebiasaan yang secara organis erat kaitannya dengan budaya secara keseluruhan, bukan suatu khasanah yang netral di mana masyarakat dapat memungut dan membeli dan juga tidak membatasi indikasi keturunan dari suatu masyarakat". ${ }^{4}$

Atas dasar kerangka teoritis di atas, menjadi relevan untuk menempatkan model kepemimpinan Yogyakarta dalam era reformasi dan demokrasi dalam analisis "budaya hukum publik, khusus hukum tata negara". Selain persoalan kepemimpinan (dalam arti sistem dan personalitasnya) tergolong ke dalam fenomena politik dan kekuasaan, juga terkait dengan berbagai kerangka normatif hukum serta prosedur yang harus dilaluinya. Kepemimpinan dalam kajian ini juga dibatasi pada eksistensi Sultan sebagai Gubernur Kepala Daerah Tingkat I.

Dasar kewenangan Sri Sultan atau Kasultanan untuk mengatur dapat dilihat dalam perjalanan sejarahnya Pada tahun 1755 kerajaan Mataram terpecah menjadi Surakarta dan Yogyakarta. Kerajaan Mataram ini pada permulaannya memang merupakan negara yang merdeka dan berdaulat. Bahkan kerajaan Mataram di bawah pimpinan Sultan Agung berani menyerang penjajah Belanda di Jakarta. Kasultanan Yogyakarta berdiri pada tanggal 13 Februari 1755 berdasarkan perjanjian Gianti antara Sultan Hamengku Buwono I dengan penjajah Belanda. Dalam perjanjian itu Kasultanan Yogyakarta oleh penjajah Belanda diakui sebagai negara, sekalipun berada di bawah kekuasaan penjajah Belanda. Sampai pada saat terakhir, Kasultanan Yogyakarta dianggap oleh penjajah Belanda sebagai negara kecil. Hal ini bisa dibuktikan oleh politik kontrak yang terakhir antara Sri Sultan Hamengku Buwono IX dan Gubernur Jenderal Hindia Belanda pada tanggal 18 Maret 1940 (Stb. 1941. No. 47).

\footnotetext{
${ }^{4}$ Untuk memahami perkembangan dan budaya hukum setidak-tidaknya kita harus memahamin substansi hukum, struktur hukum, dan budaya masyarakat. Lihat Lawrence M. Friedman, 1975, The Legal System: A Social Science Perspective, Russel Sage Foundation, New York, hal.195.
} 
Asumsi ini muncul ketika in terkait dengan etika politik Belanda dalam upaya memperkecil kekuasaan dan kekuatan masyarakat Indonesia sebagai terjajah.

Seiring perjalanan waknd, akhirnya penjajah Belanda dan Jepang hengkang dari bumi pertiwi. Setelah dikumandangkan Proklamasi Kemerdekaan pađa tanggal 17 Agustus 1945 dan revolusi Indonesia mulai berkobar di manamana dengan dahsyatnya, maka rakyat Yogyakarta pun merasa puas. Karena dalam keadaan yang sangat genting itu rakyat sewaktu-waktu dapat berhubungan langsung dan berhadapan sendiri dengan Sri Sultan. Dengan demikian setelah Sri Sultan sendiri yang memimpin daerahnya secara langsung, justru rakyat menaruh kepercayaan kepada Sri Sultan, sekalipun revolusi berkobar di Yogyakarta dengan dahsyatnya. Memahami perkembangan keadaan, dengan tegas Sri Sultan menyatakan bahwa Kasultanan Yogyakarta memihak kepada Republik Indonesia. Hal yang sama juga dilakukan oleh Sri Paku Alam. Hal ini dapat dilihat dalam Amanat 5 September 1945.

Pada zaman Hindia Belanda Jawa Tengah terdapat 4 daerah Zelbestuurendelanschappen, yaitu Kasultanan Yogyakarta, Pakualaman, Kasunanan Surakarta, dan Mangkunegaran. Kedudukan kerajaan-kerajaan itu diatur dengan kontrak politik yang diperbarui pada tiap-tiap pergantian rajanya masing-masing. Kasultanan Yogyakarta dan Surakarta diikat dengan long contract, sedangkan Pakualaman dan Mangkunegaran dengan korte verklaring. Setelah Proklamasi kemerdekaan Indonesia, mulailah terjadi perubahan penting terhadap kedudukan Kasultanan Yogyakarta dan Pakualaman. Pada tanggal 19 Agustus 1945 Presiden Republik Indonesia mengeluarkan piagam kedudukan yang menetapkan Sri Sultan Hamengku Buwono IX pada kedudukannya sebagai Kepala Kasultanan Yogyakarta dan Sri Paku Alam sebagai Kepala Daerah Pakualaman. Pada awal September 1945, terbentuklah Komite Nasional Daerah Yogyakarta yang meliputi daerah Kasultanan dan Pakualaman, dan mulai saat itulah kedua Kepala Daerah bersama menyelenggarakan pemerintah daerah dengan komite tersebut. Kemudian pada 20 Oktober 1945, Komite Nasional Daerah Yogyakarta membentuk sebuah Badan Pekerja yang diserahi tugas legisiatif dan turut serta dalam menentukan haiuan jalannya pemerintahan daerah. Dari regulasi kebijakan-kebijakan politik maupun hukum di atas maka secara yuridis bagaimana sebenarnya kedudukan hukum Kasultanan Yogyakarta tersebut?

Dengan demikian Yogyakarta adalah sebagai salah satu propinsi di Indonesia memiliki status khusus, yaitu sebagai Daerah Istimewa. Undang-Undang yang membentuk DIY sebagai daerah otonomi setingkat propinsi adalah Undang-Undang No. 3 Tahun 1950 jo. Undang-Undang No. 19 Tahun 1950. Lebih lanjut menurut Soedarisman, faktor-faktor yang menyebabkan status Daerah Istimewa Yogyakarta tetap dipertahankan adalah : 
1. Dihapuskannya fungsi dan kekuasaan Pepatih Dalem, yang menurut sejarahnya senantiasa dijadikan alat penjajah, menjelang Proklamasi Kemerdekaan RI 17 Agustus 1945, dan diambil alih fungsinya oleh Sri Sultan;

2. Karena Sri Sultan dan Sri Paku Alam beberapa sesaat setelah proklamasi kemerdekaan, yaitu tanggal 5 September 1945 dengan amanatnya yang pertama secara positif menyatakan memihak kepada $\mathrm{RI}$;

3. Bersatunya Sri Sultan dan Sri Paku Alam dalam segala tindakannya seperti dalam Amanat kedua 30 Oktober 1945 dan segala macam maklumat yang ditandatangani bersama oleh Sri Sultan dan Sri Paku Alam;

4. Dihapuskannnya fungsi dan kekuasaan Gubernur Belanda atau tyokan Jepang yang merupakan alat penjajah untuk menjajah Kasultanan Yogyakarta dan daerah Pakualaman, dengan dikeluarkannnya Amanat pertama 5 September 1945, sehingga fungsi dan kekuasaan Gubernur Belanda dan Tyokan Jepang itu diambil alih oleh Sri Sultan dan Sri Paku Alam;

5. Ditolaknya fungsi Komisaris Tinggi atau Wakilnya di Daerah Istimewa Yogyakarta, yang menurut sejarahnya seperti yang terjadi di Surakarta, ternyata justru merupakan salah satu sebab dapat dilikuidasinya Kasunanan Surakarta dan Daerah Mangkunegaran sebagai swapraja dan tidak dapatnya kedua daerah tersebut menjelma menjadi Daerah Istimewa Surakarta berdasarkan UUD 1945;

6. Diberikannnya kekuasaan kepada rakyat yang diwakili oleh Komite Nasional Indonesia DIY sehari-hari badan pekerjanya, untuk menjalankan kekuasaan legislatif dan kekuasaan untuk menentukan haluan jalannya pemerintahan dengan dikeluarkannnya Amanat kedua 30 Oktober 1945;

7. Diberikannya kekuasaan kepada rakyat dalam bentuk Dewan Pemerintah Daerah yang dipilih oleh dan dari anggota DPR DIY, untuk menjalankan kekuasaan eksekutif bersama-sama Sri Sultan dan Sri Paku Alam untuk memerintah DIY sehari-hari dengan dikeluarkannya Maklumat No. 18 Tahun 1946.

Dari pemaparan sejarah kedudukan Kasultanan Yogyakarta di atas maka secara historis dan yuridis eksistensi Keraton Kasultanan Yogyakarta menjadi ciri atau hak asal-usul status keistimewaan daerah Yogyakarta, di mana menurut Pasal 18 UUD 1945 hak-hak asal-usul tersebut diakui dan dihormati. Karena itu, bilamana ketujuh faktor tersebut dipandang sebagai adanya upaya perubahan dari aristokrasi absolutmennya ke arah perubahan sebenarnya pengorbanan pihak Keraton telah begitu besar. Menarik untuk dikedepankan pandangan Selo Soemardjan antara lain: Perubahan-perubahan pemerintahan di Yogyakarta dimulai pada pendudukan Jepang dan kemudian pada waktu 
revolusi yang diprakarsai oleh Sri Sultan sendiri. Dari seluruh warga masyarakat Jawa di Yogyakarta, Sri Sultanlah yang - sebagai penguasa tradisional yang aristokrasi dan absolut - nantinya yang paling terkena perubahan yang menuju demokrasi. Secara harfiah ia harus menyerahkan kekuasaan absolutnya, karena bukan menjadi penguasa para warganya, melainkan hanya menjadi abdi mereka. Meskipun demikian, dialah orang yang memulai perubahan itu, kemudian disusul oleh kaum bangsawan serta golongan-golongan lainnnya. Situasi perubahan cepat itu juga terjadi di Hawai. Kroeber menyebutkan kasus yang sama juga terjadi di Hawai yang menghapuskan sekte tabu kuno yang dipandang oleh raja beserta para penasehat resminya termasuk pendeta agung yang berkuasa- menghalangi penyesuaian kebudayaan rakyat dengan zaman modern." Sedangkan "International Commision of Yurits " The Dynamic Aspect of the Rule of Law in the Modern Age yang diadakan di Bangkok pada tahun 1965 merumuskan unsurunsur negara hukum sebagai berikut:

1. Perlindungan konstitusional (adanya jaminan hak individu);

2. Adanya lembaga kehakiman yang bebas dan tidak memihak;

3. Adanya pemilu yang bebas;

4. Adanya kebebasan menyatakan pendapat;

5. Adanya kebebasan berserikat (berorganisasi);

6. Pendidikan kewarganegaraan.

Sebagai negara yang mengakui zona teritori negara hukum, Indonesia sejak proklamasi mencoba mengabstraksikan unsur-unsur tersebut ke dalam konstitusi yang dinamakan UUD 1945. Selanjutnya adanya pengakuan persamaan kedudukan di depan hukum dalam UUD 1945 Pasal 27 ayat (1) disebutkan, bahwa

"Segala warga negara bersamaan kedudukannya di depan hukum dan pemerintahan, dan wajib menjujung tinggi hukum dan pemerintahan itu dengan tidak ada kecualinya".

Dalam negara demokrasi, salah satu unsur penting yang tidak bisa ditinggalkan adalah adanya supremasi hukum. Artinya hukum dijadikan sebagai pijakan dalam setiap tindakan, baik oleh warga negara maupun pemerintah. Hukum inilah yang diharapkan dapat menciptakan the rule of game dalam berbagai bidang kehidupan, baik politik, sosial, ekonomi dan bidang-bidang lainnya. Demokrasi seperti yang dikatakan Bonger, bukanlah suatu bentuk pemerintahan yang timbul dengan sendirinya, tetapi tumbuh dan berkembang seperti semua lembaga-lembaga masyarakat, secara evolutif.

Senjelasan sistematis mengenai perubahan sosial di Yogyakara bisa baca Selo Sumardjan, op.cit, hal. 324 
Menurut Nurcholish Madjid (1999), transisi menuju demokrasi adalah proses, seperti demokrasi itu sendiri adalah merupakan proses, dan demokrasi selalu "dalam keadaan terus bergerak", baik secara negatif atau positif (maju). Karena itu menurutnya demokrasi tidak dapat diterjemahkan "sekali untuk selamanya". Bila suatu masyarakat berhenti berproses menuju yang lebih baik, dan terus lebih baik lagi, maka masyarakat itu tidak lagi demokratis.

\section{Budaya Hukum dalam Realisasi Otonomi Daerah}

Salah satu aspek penting yang terkait dengan boleh dan tidaknya suatu wilayah memiliki ciri keistimewaan terkait dengan prinsip utama Indonesia sebagai negara hukum (rechtstaats). Segala kekuasaan dan kewenangan negara dan rakyatnya seluruhnya harus dibatasi oleh peraturan hukum (baik UndangUndang atau yang lebih rendah dari itu). Penentuan DIY dan Aceh sebagai daerah Istimewa misalnya didasarkan kepada pasal 18 UUD 1945. Keistimewaan yang dimiliki oleh setiap daerah menjadikan sistem pemerintahan mekanisme desentralisasi yang asimetris di mana nilai-nilai demokrasi tetap tersemai dalam keaneka ragaman namun tetap dalam pilar Negara Kesatuan RI. Pemahaman demikian ini selain tidak bertentangan dengan nilai demokrasi juga secara juridis formal dijamin keberadaan budaya hukum untuk dipertahankan.

Dalam Bab IV tentang arah kebijakan, GBHN 1999 menggariskan arah kebijakan pembangunan di bidang hukum sebagai berikut: Pertama, mengembangkan budaya hukum di semua lapisan masyarakat untuk terciptanya kesadaran dan kepatuhan hukum dalam kerangka supremasi hukum dan ditegakkannya negara hukum; Kedụa, menata sistem hukum nasional yang menyeluruh dan terpadu dengan mengakui dan menghormati hukum agama dan hukum adat serta memperbaharui perundang-undangan warisan kolonial dan hukum nasional yang diskriminatif, termasuk ketidakadilan gender dan ketidaksesuaiannya dengan tuntuta' reformasi melalui program legislasi; Ketiga, menegakkan hukum secara konsisten untuk lebih menjamin kepastian hukum, keadilan dan kebenaran, supremasi hukum, serta menghargai HAM.

Untuk membatasi timbulnya kekuasaan negara dengan menggunakan kekuasaan belaka (machstaats), secara teoritis negara harus menjamin tegaknya beberapa pilar dasar demokrasi. Supremasi hukum dengan mengedepankan kesederajatan (equality before the law), pemilihan umum (general election), peradilan yang bebas (independent trial), kemerdekaan pers (freedom of press) dan perlindungan terhadap HAM (the protection of human rights), dan peradilan tata usaha negara (administrative tribunal). Kelima pilar ini, dalam prakteknya secara nasional masih sangat jauh panggang dari api. Sejak zaman penjajahan pemerintah Belanda akar pelaksanakan hukum yang disḳriminatif tersebut telah disengaja diciptakan. 
Indonesia dalam perjalanan sejarah hukum, dikenal dengan pluralisme hukum. Berdasarkan Pasal 131 I.S., penerapan hukum perdata bagi penduduk Indonesia ada tiga golongan, yaitu : (a) golongan Eropa di Hindia Belanda, hukum perdata konkordansi yang berarti KUH Perdata dan KUHD; (b) golongan Bumi Putera, Hukum Perdata Adat (dan Hukum Isiam); (c) golongan Timur Asing, yairu warga Tionghoa, dan Arab sejak tahun 1917 diberiakukan KUH Perdata dan KUHD dengan pengecualian mengenai perkawinan, kongsi, adopsi, berlaku hukum asal negara tersebut. Fakta hukum tersebut bukan saja secara implisit Indonesia mengakui kedudukan keaneka ragaman hukum. melainkan juga mengandung konsekuensi bahwa dalam perubahannya tidak dapat secara otomatis diberlakukan.

Sampai sekarang masih terdapat dan berlaku hukum atau Undang-Ujndang produk kolonial di atas berdasarkan asas konkordansi, asas kodifikasi hukum, asas unifikasi hukum pidana, dan asas pluralisme hukum sebagaimana yang dijelaskan ${ }^{r}$ dalam Penjelasan UUD 1945. Meski dalam realitas perkembangannya Undang-Undang tersebut dirasakan menimbulkan persoalan dan pertentangan dengan nilai-nilai demokrasi khususnya. Termasuk dalam hal ini, bagaimana UUPA No.5 / 1960 baru dapat dilaksanakan di Yogyakarta sekitar tahun 1984-an. Ini tidak berarti bahwa DIY tidak memiliki kesadaran hukum dalam bidang pertanahan, melainkan pengaturan tanah di Yogyakarta sudah mulai diberlakukan sejak dihilangkannya politik tanam paksa.

Untuk menjawab persoalan seberapa jauh kepemimpinan di DIY telah merealisasikan pilar-pilar negara hukum adalah sama sulitnya dengan memberikan ukuran standar negara hukum terhadap kepemimpinan nasional. Namun, yang menjadi persoalan secara juridis dan sosiologis adalah, apakah istilah "ISTIMEWA dalam Daerah Istimewa Yogyakarta" tergolong diskriminatif atau tidak dalam konteks kehidupan demokrasi.

Dalam hukum baik secara teoritis maupun praktis, istilah "Istimewa" berbedá dengan pengertian diskriminatif dan tidak bisa diartikan sebagai sama dengan diskriminatif (pengucilan). Sebab, pertama diskriminatif lebih diterapkan pada sinrasi perbedaan perlakuan terhadap subyek hukum, di suatu tempat pada suatu masa atau kekuasaan tertentu. Di segi lain, istimewa berbeda dari diskriminatif oleh karena keistimewaan hanya diberikan dan merupakan subyek hukum khusus, atas suatu kualitas tertentu, dan karena itu tidak bisa diberlakukan pada subyek hukum umum. Situasi keistimewaan ini berbeda dari diskriminasi didasarkan kepada azas hukum, tidak ada peraturan hukum yang beriaku tanpa pengecualian (There is no rule without exception). Menarik untuk diperhatikan mengenai konsep Dwi-tunggal Kepemimpinan di Yogyakarta yang dikemukakan oleh Ki Tembong M. Sandry.

Keistimewaan Yogyakarta dalam kepemimpinan bisa dikemukakan tiga argumentasi. Pertama. konsep dwi-nunggal antara Kasultanan dan Puro 
Pakualaman merupakan simbol kekuatan kultural, spiritual yang mengarah pada kekuatan moral, maka yang ditegakkan adalah nilai-nilai kebajikan (kearifan tradisional). Sepanjang pengalaman sejarah ${ }^{6}$ konsep dari dwi tunggal ini mulus tanpa celah. Kedua, konsep dwi tunggal masih tetap relevan dengan kultur Yogyakarta sebab kedudukan kepemimpinan Sri Sultan dengan Pakualaman masin didukung masyarakat. Ketiga, konsep dwi tunggal kepemimpinan Yogyakarta tidak bertentangan dengan peraturan hukum. Sebab sesuatu yang istimewa, baik secara teoritis maupun praktis tidak identik dengan diskriminatif. Sebab, perlakuan diskriminatif itu bisa terjadi bilamana ketentuan hukum tersebut ditetapkan secara umum kepada subjek hukum yang sama.

Karena itu, bilamana keistimewaan dalam proses pemilihan Gubernur dan Wakil Gubernur masih dipandang rancu dalam hukum positif, tidak berarti esensi demokrasi terkurangi. Kehadiran praktek-praktek kenegaraan di luar ketentuan hukum tertulis, tetapi mendapatkan pembenaran dari hukum tidak tertulis merupakan penjelasan yang rasional. Situasi hukum seperti in menunjukkan bahwa Sri Sultan dan Paku Alam memperoleh prioritas dalam pemilihan Kepala Daerah didasarkan kepada hukum adat.

Hasil poling panitia Yayasan Tuna Bangsa, yang mengindikasikan kesepakatan (ab) bahwa setiap warga mempunyai hak yang sama untuk memilih dan dipilih tidak dapat diragukan lagi $(96,6 \%)$ polling surat kabar. Namun menjadi berubah sangat drastis $(59,8 \%)$ ketika unsur Sultan di DIY dilibatkan. Poling ini menunjukkan bahwa keistimewaan yang diberikan sebagai ketentuan khusus. Karena itu, adanya pengecualian dalam hukum juga dibenarkan dalam kehidupan demokrasi. ${ }^{7}$

Pertama, keistimewaan yang menjadi atribut DIY salah satunya diberikan kepada keturunan Sultan Yogyakarta untuk Gubernur dan puro paku Alaman sebagai Wagub. Dilihat dari segi sejarah perkembangan hukum (history of legal development), "keistimewaan Yogyakarta telah merupakan fakta politik atau juga hubungan hukum yang amat panjang. Timbulnya kesepakatan tersebut semula dikukuhkan sejak zaman pemerintah kolonial Belanda dengan apa yang disebut sebagai "Political Contract".

Perjanjian antara status istimewa ini juga diakui setelah kedudukan Indonesia dapat melepaskan diri dari penjajahan Belanda di buat antara Sri Sultan

A Tulisan P.J. Suwarno, Gubernur Daerah Istimewa Yogyakarta dan Ki Tembong M. Sandry, Urgensi Dwi Tunggal Kepemimpinan di DIY, 2000, Kedaulaton Raķa.' Uniuk mencari dasar hukum Keistimewaan tidak bertentangan dengan hukum. pertama bisa dilihat dari pasal 18 UUDD 1945, UU DIY No 3/1950. Begitu juga diperkuat oleh pasal 122 UU No 22/1999. Isinya menegaskan Keistimewaan untuk propinsi Daerah Istimewa Aceh dan Propinsi Daerah Istimewa Yogyakarta adalah tetap Sultan dan Paku Alam sebagai Gubernur dan Wagub DIY.

' Lihat. hasil polling. oleh Ahmad Zaini Abar. 2001. Hasil Temuan Polling Survey. Ikhwal masa Depan Kepemimpinan Yogyakarta. Dari Rasionalitas Kularal Menuju Rasional Demokrasi Yogyakarta.hal. 2 
Hamengkubuwono IX dengan LA Adam, pada 1 Maret 1940. Perjanjian ini dikuatkan oleh Gubernur Hindia Belanda, A.W.L. Tjarda Van Starkendorg, yaitu dengan surat Maklumat No 1945. Pengakuan dari keistimewaan Yogyakarta juga telah diberikan oleh presiden pertama RI, Ir Sukarno pada tanggal 19 Agustus $1945 .^{8}$ Komponen sejarah pembentukan hukum itu memperlihatkan bukti bahwa Daerah Istimewa diakui oleh Pasal 18 UUD 1945.

Ciri keistimewaan kedua, secara kultural Yogyakarta sebagai kota pelajar dan budaya memiliki nilai-nilai kesejarahan yang cukup tinggi dan dapat menarik perhatian tamu-tamu domestik dan asing. Usaha untuk melestarikan peninggalan masa lalu (the heritage of humankind) berbentuk Istana Kasultanan Yogyakarta Hadiningrat dan segala isinya yang amat berharga. Dan karena itu tidaklah mudah penanganannya bilamana mekanisme hubungan tradisional masyarakat dengan Sultan tidak dipertahankan. Keadaan seperti ini memang dapat menimbulkan dilema. Seperti lingkungan budaya kota dibelahan muka bumi Yogyakarta selalu menghadapi dilema pertentangan mempertahankan peninggalan lama dan menciptakan fasilitas baru yang mampu mewadahi kehidupan moderen. Sama halnya dengan kehidupan masyarakat Jepang di mana nilai-nilai tradisional bisa dirasionalisasikan ke dalam pranata modern. ${ }^{9}$

Konsekuensi dari keistimewaan tersebut, memberikan peluang kepada Sultan sebagai pimpinan Daerah. Wewenang dan tanggung jawab Sultan sebagai Gubernur memang memiliki fungsi ganda. Pertama, Sultan sebagai pimpinan pemerintah tingkat propinsi yaitu penyelenggara pemerintah pusat yang berada di daerah. Kedua, Sultan sebagai wali (guidance) dari struktur keluarga keraton dan terhadap tempat peninggalan zaman kuno. Dalam skala nasional, usaha pelestarian cagar budaya, termasuk di dalamnya keraton telah didukung oleh UU No 5. Tahun 1992 tentang cagar budaya.

Tugas utama sebagai wali keraton adalah pemelihara tradisi termasuk di dalamnya peninggalannya tidak akan mudah dilestarikan jika penguasa daerah tidak dipilih bukan dari warga keraton. Tidak akan menjadi juga terkait dengan peranannya dalam mempertahankan keraton sebagai warisan peradaban umat manusia (Preservation of the Cultural Heritage of Mankind). Untuk usaha melestarikan warisan budaya tersebut, PBB selain akan memberikan arahan juga berbagai kemungkinan untuk membantu tindakan lanjut. ${ }^{10}$ Kedudukan dan wibawa Sultan masih dapat dipertahankan dalam suasana reformasi dan demokrasi tidaklah berlebihan. Beberapa negara di Eropa seperti Inggris,

\footnotetext{
- Pembahasan detil mengenai Sejarah dan Monograpi Yogyakarta bisa dilihat Soedarisman Pourwokoemo,op. cit. hal. 266. Dan juga buku Monografi DIY tahun 1979 kantor pusat Data Propinsi DTY, hal. 254.

${ }^{9}$ Lihat Laretna T. Adisakti, 2001, Kolaborasi inovasi dan Disain Lingkungan Budaya Yogyakarta, Kedaulasan Rakyat, 14-15 Januari

${ }^{10}$ Untuk lebih lanjut persoalan ini ditegaskan dalam pasal 18, dari Rekomendasi UNESCO 19 November 1974,
} 
Perancis, Spanyol dan Belanda, yang menganut sistem kekuasaan pemerintahan parlementer, di mana raja merupakan bagian sah dari sistem kekuasaan terbukti tidak menjadi penghalang pertumbuhan demokrasi.

Meskipun demikian usaha-usaha untuk membuka kesempatan lebih longgar bagi hak politik masyarakat tidaklah menutup kemungkinan. Namun, prosedur hukum yang secara sah dapat dilaksanakan secara lokal. Sebelum anggota DPRD memainkan peranan secara efektif, kedudukan Gubernur dan Wagub diangkat oleh pemerintah Pusat. ${ }^{11}$ Namun, hal tersebut tidak lagi dipergunakan dalam pemilihan Gubernur dan Wakil Gubernur pada waktu sekarang.

Setidaknya terdapat dua skenario yang bisa điajukan bagaimana keistimewaan Sultan dalam kepemimpinan masa depan masih tetap relevan dan seiring dengan era demokrasi. Skenario pertama, amandemen Pasal 18 UUD 1945. Fungsi amandemen selain amanat Daerah istimewa perlu dihapuskan, juga memberikan peluang agar PERDA DTY yang akan dibuat anggota DPRD tidak akan terjadi pertentangan. Perubahan Perda (Peraturan Daerah) mengenai keistimewaan Sultan dan keturunan Puro Paku Alaman sebagai Gubernur dan Wagub secara konstitusional sesuatu yang secara bisa dilakukan. Akan tetapi, secara kultural siapa di antara anggota-anggotanya berani melakukannya oleh karena ada budaya ewuh pakewuh sehingga perubahan agaknya dimungkinkan. Peraturan hukum tidak ada larangan, tapi tidak cukup kuat kehendak untuk mendobrak tradisi sungkan, hutang budi. Lebih dari itu, istilah Daulat Suitan yang muncul dari rakyat bisa menjadi sumber hukum di DIY yang perlu dipertimbangkan. ${ }^{12}$

Skenario kedua, yaitu dengan melakukan referendum tingkat lokal. Poling yang saat ini sedang kita uji sebenarnya bagian dari proses pembuatan hukum secara langsung melalui rakyat. Suatu pemungutan pendapat yang secara substansial berisi permohonan kepada seluruh rakyat DIY untuk memberikan pendapatnya (YA atau TIDAK) sebagai punusan hukum "People's Law" dalam apakah keturunan raja masih memiliki hak istimewa. Referendum dalam konteks realisasi Otonomi Daerah tampaknya tidaklah bertentangan secara konstitusional. Sebab, inti referendum bukan kehendak memisahkan diri atau self-determination. melainkan lebih menentukan pada segi-segi

mengenai Rekomendasi Pendidikan dan Kerjasama Kesepahaman Internasional. dan Kerjasama Perdamaian dan Pendidikan berkaitan dengan HAM dan Kebebasan dasar lainya. Lihat World Compaign for Human Rights. Human Rights: A Compilation of International Instruments. Vol I. (Second Part) Universal Instrument. UNO, New' York, 1993. hal. 599.

"Lihat lebih lanjut penjelasan UU No 1/1957 tentang Undang-Undang Pokok Daerah dan juga tulisan J. Thontowi. 2000. "Penguasaan dan Pemikiran Tanah yang Diskriminatif: Perspektif Hukum Internasional dan Hukum Nasional. Jumal Hukum. No 13. Vol 7. hal. 43.

12 Preseden hukum tata negara yang relevan dengan konteks in, adalah ketika Himawan Darmawan dari PAN akan diajukan sebagai rival pencalonan Gubernur dua tahun yang lalu 1998 menyalahi hukum kebiasaan masih berlaku efektif. 
kepuasan masyarakat. Hal ini akan sama halnya dengan tuntutan seorang gubernur harus diwakili oleh putra Daerah. "Suan aspirasi lokal yang dalam prakteknya cukup penting untuk diperhitungkan. Praktek referendum juga diterapkan dalam rangka membuktikan keberhasilan yang sebenarnya dalam mengobati kekecewaan terhadap perbuatan anggota-anggota parlemen". ${ }^{13}$

Ciri budaya ketiga terkait dengan keistimewaan Yogyakarta adalah adanya indikasi fungsi Suitan dalam konteks dakwah dan pelestarian budaya Islam. Predikat Sultan adalah simbol tradisional raja Islam yang mewakili figur pribadi dan pimpinan umat. Bukan saja karena secara simbolik keistimewaan itu terietak pada gelar Sultan, sebagai Khalifatullah Sayyidin Panotogomo (wakil Tuhan pengatur agama), melainkan juga terbukti terdapat langkahlangkah konkrit ke arah menjadikan Yogyakarta sebagai tempat membingkai rekonsiliasi dan perdamaian tampak konkrit. Misalnya, keberadaan Sultan sebagai tempat bertumpunya atau mediator atas penyelesaian konflik politik secara lokal, nasional, dan bahkan internasional. Sekurang-kurangnya perlu dipertanyakan mengapa inisiatif untuk meredam konflik di Timor Timur tahun yang lalu dilaksanakan oleh mahasiswa Timtim di Yogyakarta. Dalam kasus Sampit, melibatkan pertikaian berdarah suku Dayak dengan Madura, gagasan rekonsiliasi juga tumbuh dari Yogyakarta. Bahkan ada isyarat, pertemuan Kubro empat tokoh politik akan dilaksanakan di Yogyakarta. Peranan Sultan ke $\mathrm{X}$ sebagai fasilitator dalam proses pembuatan perkampungan Islam Internasional telah menunjukkan perlunya keistimewaan itu tetap dipertahankan.

\section{Keistimewaan Dalam Pengaturan dan Penguasaan Tanah}

Bagian ini akan mendeskripsikan tentang keistimewaan dalam kaitannya dengan wewenang Keraton dalam pengawasan tanah-tanah tertentu, dan implikasinya terhadap kedudukan warga keturunan Tionghoa. Dalam realitas pendukung hak dan kewajiban tidak hanya orang sebagai manusia pribadi, akan tetapi dikenal pula badan hukum. Badan Hukum adalah subjek hukum dalam arti yuridis, sebagai gejala dalam hidup bermasyarakat, sebagai badan ciptaan manusia pribadi. Badan hukum ini menurut ketentuan Pasal 1653 KUH Perdata ada tiga macam klasifikasi berdasarkan eksistensinya, yain:

1. Badan hukum yang di bentuk oleh pemerintah (penguasa), seperti badanbadan pemerintah, perusahaan-perusahaan negara;

2. Badan hukum yang diakui oleh pemerintah (penguasa), seperti Perseroan Terbatas, Koperasi;

3. Badan hukum yang diperbolehkan untuk suatu tujuan tertentu yang bersifat

${ }^{13}$ Geoffrey de Q dan Walker, Intiarive and Referendum: The people's Lau. CIS Policy Monographs. 10. The Centre for Independent Studies, New Southwales, hal. 198. 
ideal, seperti yayasan (pendidikan, sosial, budaya, keagamaan dan lainlain) $^{14}$

Badan hukum yang dibentuk oleh pemerintah adalah badan hukum yang sengaja diadakan oleh pemerintah untuk kepentingan negara, baik lembagalembaga negara maupun perusahaan-perusahaan milik negara. Badan hukum ini dibentuk oleh pemerintah dengan undang-undang atau dengan peraturan pemerintah. Apabila dibentuk dengan undang-undang, maka pembentuk badan hukum itu adalah presiden bersama dengan. DPR RI. Apabila dibentuk dengan peranran pemerintah, maka pembentuk badan hukum itu adalah Presiden sebagai Kepala Pemerintahan.

Dilihat dari wewenang hukum yang diberikan kepada badan hukum, maka badan hukum dapat pula diklasifikasikan menjadi dua, yaitu :

1. Badan hukum publik (kenegaraan), yaitu badan hukum yang dibentuk oleh pemerintah dan diberi wewenang menurut hukum publik.

2. Badan hukum privat (keperdataan), yaitu badan hukum yang dibentuk oleh pemerintah, diberi wewenang menurut hukum perdata. Badan hukum keperdataan ini mempunyai bermacam ragam tujuan keperdataan, termasuk di dalamnya kemungkinan lembaga seperti Keraton dapat menguasai tanah. Jika penguasaan atau pemilikain tanah bagi Keraton diperkenankan oleh hukum, maka apakah dualisme pelaksanaan hukum tanah antara UUPA

No. 5/1960 bersifat Nasional dan model Keraton harus dihapuskan?

Meskipun konsep penguasaan tanah oleh raja-raja dianggap sebagai pemilik segala sesuatu yang ada di dalam kerajaan, usaha memberdayakan tanah pertanian untuk rakyat telah dipelopori sejak zaman Mataram pada tahun 1918. Peristiwa ini sebenarnya merupakan reaksi atas dihapuskaninya sistem Tanam Paksa. Suatu ketentuan hukum (undang-ùndang 1834 No. 22, terbitan Hindia Belanda) di mana petani di Jaẉa dipaksa untuk menyerahkan seperlima dari tanahnya dan menggarapnya untuk menanam tanaman komersial untuk pemerintah kolonial. Secara berangsur-angsur di daerah, dan juga di Yogyakarta khususnya memutuskan untuk memperhatikan kesejahteraan penduduk. Program Land Reform telah dimulai 1912 atas dasar kaum tani tidak boleh hanya dibebani dengan'berbagai kewajiban tetapi mereka juga harus diberi hak-hak. ${ }^{15}$

Secara hukum realisasi UUPA No 5/1960 di DIY memang tidak sesuai dengan perintah UU tersebut oleh karena DIY secara formal baru menerapkan. sekitar tahun 1984. Kenyataan penerapan UUPA tersebut menunjukkan adanya

14 Pembahasan raengenai Badan Hukum bisa dibaca Ali Rido, Badan Hukom dan Kedudukan Perseroain, Perkumpulan Koperasi, Yoyasan dan Waqaf. Alumni, Bandung. ha!. 57. Untuk mengerahui jenis badan hukum privat dan publik bisa dilinat Chidir Ali, 198T, Badan Hukum, Alumni, Bandung, hal. 58-59.

ss Selo Soemardjan,op.cit. hal 180. 
dualisme hukum. Ni'matul Huda menegaskan dualisme tersebut antara lain. di satu pihak berlaku undang-undang Daerah, dan di pihak lain berlaku UU Pusat. Akibatnya, dualisme dalam hukum Agraria di DIY jika memberikan ketidakpastian hukum, serta tidak terwujudnya unifikasi hukum.

Namun, dualisme penggunaan hukum tanah itu menjadi kurang berarti ketika dihadapkan pada kenyataan sebagai berikut. Pertama, pemerintah pusat masih mentolelir untuk tidak menerapkan UUPA sepenuhnya. Hal ini berdasarkan kepada Keppres Presiden No 33/1984 dan karena itu pengurusannya diserahkan kepada Pemda DIY. ${ }^{16}$ Alasan lain yang sangat penting adalah DIY telah memiliki ketentuan hukum yang lahir sebelum UUPA diundangkan. Hadisuprapto mengemukakan "ternyata Daerah Istimewa Yogyakarta telah lebih dahulu membuat aturan hukum pertanahan yang memberikan ketentuan tentang hak-hak atas tanah, pemindahan hak atas tanah, dan sebagainya. ${ }^{17}$ Namun, diakui bahwa model penguasaan tanah oleh keraton masih bersifat feodal oleh karena sifat pemilikan yaitu terbatas pada hak memakai (anggaduh).

Kesiapan DIY untuk melaksanakan UU Otonomi Daerah memang sangat beraneka ragam. Pada umumnya kendala-kendala yang dihadapi seperti ditemukan oleh Ni'matul Huda dalam penelitiannya, ${ }^{18}$

a. Kecilnya sumber pendapatan daerah karena sebagian urusan masih belum dilimpahkan ke Daerah Tingkat II;

b. Pelimpahan urusan dari Pemerintah Pusat maupun Daerah Tingkat I tidak disertai dengan personil, pembiayaan, dan perangkatnya sehingga membebani Daerah;

c. Terbatasnya SDM baik kualitas maupun kuantitas;

d. Potensi kekayaan daerah yang ada belum dikelola secara optimal.

Problem hukum yang paling mendasar selain ciri keistimewaan DIY adalah bagaimana posisi hukum Keraton bisa memiliki dan menguasai tanah. Jika berdasarkan kepada Undang-Undang No. 3 tahun 1963 (tentang penetapan badanbadan hukum yang dapat menguasai tanah) maka Keraton tidak termasuk badan hukum. Menurut ketentuan tersebut badan hukum antara lain, pertama, bankbank yang didirikan oleh negara. Kedua, perkumpulan-perkumpulan Koperasi yang didirikan berdasarkan UU No. 79 tahun 1958. Ketiga Badan-badan keagamaan, yang ditunjuk oleh Menteri Pertanian dan Agraria setelah mendengar Menteri Agama. Keempat, Badan-badan sosial dan ditunjuk oleh Menteri Dalam.

\footnotetext{
${ }^{16}$ Ni'matul Huda. 1997. Penvelenggaraan Koordinasi antara Pemerintah Daerah Tingkat I DIY dengan Keraton Yogvakarta Dalom Pengaruran Tanaf, Tesis Magister Hukum. Universitas Padjadjaran, Bandung, hal, 14.

${ }^{17}$ Hadisuprapto.1977, Jhtisar Perkembangan Hukum Tanah DIY.Penerbit Karya Kencana, Yogyakara, hal.23.

18 Ni'matul Huda, 1997, Persiapan Pelaksanaan Otonomi Daerah dengan Titik Berat pada Daerah Tingkat II

${ }^{14}$ Suatu penelitian yang cukup komprehensif mengenai sinuasi pertanahan di Yogyakarta, lihat Ni'matul Huda,
} 
Negeri dan Dirjen Agraria. ${ }^{19}$ Namun, ketentuan itu menjadi kurang relevan oleh karena sesuatu yang telah diaur oleh masyarakat sejak zaman dulu sebagai subyek hukum akan tetap menjadi subyek hukum dewasa ini.

Karena inu, keistimewaan DIY yang diberikan hak Guna Bangunan/Pakai (20 tahun) terhadap penduduk keturunan Cina adalah jelas tergolong sebagai tindakan diskriminatif dalam hukum. Namun, anggapan diskriminatif terhadap warga keturunan tersebut menjadi tidak berlaku lagi (valid) oleh karena sebenarnya banyak warga keturunan yang melakukan transaksi jual beli tanah di bawah tangan. Suatu perjanjian jual beli tanah yang berlangsung di mana pembeli asli (warga keturunan) biasanya meminjam nama seseorang asli Jawa (tentunya yang dikenal dekat) untuk terlibat dalam transaksi jual beli tersebut. Dengan demikian, jikapun keistimewaan dalam penentuan hak-hak atas pemilikan tanah itu diskriminatif, maka sebenarnya tidak seluruhnya benar.

Pemberian hak pemilikan tanah oleh penguasa daerah, dalam hal ini pemerintah DIY terhadap warga keturunan secara jelas kebijakan hukum dan politik yang diskriminatif dan karena itu bertentangan dengan semangat hukum dan spirit demokrasi. Karena inu, pertama istilah terms of address, seperti penyebutan "warga keturunan" dan istilah pribumi tidak lagi dipergunakan dalam percakapan, baik formal maupun non-formal sebagai warga negara. Kedua, pemberian hak yang sama dalam pemilikan atas tanah periu disesuaikan dengan nilai-nilai keadilan dan kepantasan (equity), sesuai diatur UUPA No. 5/1960.

Namun, kendala penerapan UU tersebut terbentur dengan UU No. 3/ 1950 yaitu mengenai Pembentukan Daerah Istimewa Yogyakarta. Dalam kenyataan bahwa UUPA No. 5/1960 baru dilaksanakan sejak tahun 1984, itupun tidak pernah terjadi sebelum dikeluarkannya Keputusan Presiden No 33 tahun 1984. Meskipun demikian, seperti dikatakan oleh kesimpulan penelitian Ni'matul Huda, terjadinya ambivalensi penerapan atribusi hukum tanah selain karena adanya UU No. 3 tahun 1950 tentang pembentukan DIY, khususnya tanah bekas swapraja dan bekas tanah swapraja (bagian A dan B) bertentangan dengan misi diterapkannya UUPA No. 5 tahun 1960 . Usaha konkret tersebut selain kepemimpinan DIY memperlihatkan komitmen untuk mendukung tegaknya supremasi hukum, khususnya usaha merealisasikan UU No 22/1999, lebih penting dari itu adalah citra positif kepemimpinan DIY yang adil dan makmur, sejuk, aman, dan đamai semakin terbukti secara konkrit dalam masyarakat.

Sebenarnya apa yang menjadi persoalan kebebasan dan batasan akan hak seseorang sangat tergantung kepada tujuan dari peraturan hukum dibuat. Misalnya ketika hak Guna Bangunan/Usaha diberikan oleh kebijakan hukum

2000, Beberapa Kendala Dalam Penyelesaian Starus Hukum Tanah Bekas Swapraja di Daerah Istimewa Yogyakarta. Jurnal Hukum, No 13. 7 April, hal. 102. 
DIY terhadap "warga keturunan" tidaklah berarti bahwa terdapat perbedaan keputusan antara apa yang diklaim sebagai pemilikan dan penguasaan. Situasi ini menjadi sangat relevan oleh karena kebebasan tanpa batas tidak pernah sepenuhnya ada dalam kehidupan ini. Peranan Keraton sebagai subyek hukum dalam penguasaan tanah di sekitarnya masih tetap terkesan dominan. Menarik untuk diperhatikan penelitian $\mathrm{Ni}^{\prime}$ matul Huda antara lain menyebutkan, dalam proses perizinan meliputi izin lokasi, izin mendirikan bangunan dan izin tempat usaha, pemerintah Kotamadya Yogyakarta mensyaratkan adanya izin dari pihak Keraton, terutama bilamana berkaitan dengan penggunaan tanah-tanah yang dikuasai Keraton. Faktor lain yang menjadi kendala hingga kini dalam pengaturan tanah yang tidak terdapat kepastian yaitu mengenai status tanah, administrasi pertanahan, kelembagaan. ${ }^{20}$

Menarik untuk diperhatikan, pandangan Hegel mengenai adanya kebebasan dalam pemilikan terhadap harta benda secara mutlak. "Ia menegaskan, adalah mungkin saja seseorang menjadi pemilik terhadap sesuatu benda tetapi dalam waktu yang sama bukan pemilik dari nilai benda itu. Jika seseorang keluarga tidak dapat menjual dan menggadaikan barangnya, ini berarti bahwa ia bukan pemilik atas nilai benda tersebut. Tetapi sejak bentuk barang tidak didasarkan kepada konsep harta benda, maka setiap pembatasan mengenai pemilikan (pemilikan feodal dan wasiat) umumnya tidak terwujud". ${ }^{21}$

Karena itu, menurut pasal 5 dari Deklarasi PBB tersebut, negara-negara pihak dilarang untuk mengucilkan dalam berbagai bentuk dan memberikan jaminan akan hak setiap orang, tanpa ada perbedaan ras, warna kulit, kebangsaan dan asal usul, untuk duduk sejajar di depan hukum, terutama dalam ayat (d) bagian V mengenai hak untuk memiliki sesuatu benda (The rights to own property alone as well as in association with others).

Berdasarkan kerangka pemikiran teoritis mengenai kepemilikan atas benda tidak ada yang mutlak maka sebenarnya terdapat kesamaan dengan kasus warga keturunan di DIY. Di satu pihak Sultan memiliki dan menguasai tanah sebagai keistimewaan mengatur dan mendistribusikan atas tanah yang dikuasai. Namun demikian, warga keturunan tetap memiliki hak nilai tanah yang dikuasainya, meskipun hanya pada batas hak Guna Bangunan. Akibatnya warga keturunan hanya mempunyai hak Guna Bangunan selama 20 s/d 30 tahun. Namun, warga keturunan tetap memiliki hak atas nilai sebidang tanah yang dikuasainya. Sebaliknya, Sultan atau Raja dianggap sebagai pemilik

o) Lihat kesimpulan Ni'maul Huda, op.cit. hal. 141

2I Untuk perjelasan lanjut bisa dilihat Timothy O'Hogan, 1984, The End of Law, Basil Blackwell. Oxford, hal. 36. World Campaign for Human Rights, 1993, A Compilation of insemational Instruments (VoI I) Universal Instrument. UNO. New York, hal.70.

22 Lihat Deklarasi PBB mengenai Pembatasan terhadap segala bentuk diskriminasi ras dan golongan, Intemarional Convention on the Elimination of all Racial Discrimination, 21 Desember 1965. 
tanah tersebut, tetapi dalam kenyataan mereka tidak memiliki atau menikmari atas nilai in.

Akan tetapi untuk mendapatkan kepastian hukum, maka fungsi hukum selain ketertiban juga memilki njuan yairu keadilan. Karena im, selain istilah warga keturunan perlu ditiadakan karena tidak sesuai dengan konvensi internasional, termasuk ketentuan HAM nasional. ${ }^{22}$ Lebih dari itu, anggota DPRD DIY harus mengusahakan terciptanya hak dan keadilan antara warga di DIY seperti perlunya istilah keurunan dipertimbangkan, lebih dari itu bagaimana DPRD bisa membatasi adanya monopoli tanah di kota-kota oleh orang-orang tertentu. Usaha untuk membatasi timbulnya monopoli atas penguasaan tanah oleh warga keturunan dapat menimbulkan kerawanan sosial secara lebih makro.

\section{E. Penutup}

Dari uraian di atas dapatlah ditarik pandangan bahwa transformasi nilai dan norma bagi kepemimpinan DTY di masa mendatang perlu harmonisasi dengan nuansa era reformasi yang mengedepankan sistem politik dan pemerintahan yang rasional dan demokratis. Tuntutan semua warga memiliki hak yang sama dalam proses pencalonan pemilihan Kepala Daerah Tingkat I (Propinsi) tidak bisa diabaikan dalam suasana reformasi. Namun, proses perubahan yang menuju ke era yang lebih demokratis tersebut tidak harus menempatkan asumsi Keistimewaan DIY sebagai suatu atribut diskriminatif dalam hukum dan demokrasi. Keistimewaan Yogyakarta, khususnya dalam model kepemimpinan, lebih merupákan kondisi khusus yang dalam parameter, konstitusi dan hukum yang hidup dalam masyarakat (living law) diakui sebagai pengecualian (exception). Bahkan model pemilihan tersebut telah merupakan bagian dari praktek ketatanegaraan yang tertulis atau hukum kebiasaan (Customary Law) Daerah Istimewa Yogyakarta. Namun, arus reformasi lambat laun tidak akan terus menggelinding secara efektif seiring dengan tumbuhnya kesadaran hukum dan politik masyarakat DIY, sebagaimana data dikemukakan oleh Yayasan Tuna Bangsa.

Berbeda halnya keistimewaan tersebut diterapkan dalam kaitannya dengan peranan Keraton sebagai subyek hukum dalam pemberian hak atas tanah termasuk dalam hal status warga keturunan. Pengaruh dari Kasultanan dalam kaitannya dengan penguasaan tanah memang masih cukup signifikan dan tentu akan terus berdampak terhadap realisasi UU No. 22/1999. Bukan saja banyak bukti, termasuk UUPA No. 5/1960 diberlakukan di Yogyakarta sekitar 1984. Berbagai modifikasi oleh karena banyaknya aneka ragam pemilikan 
tanah, termasuk kedudukan tanah-tanah keraton yang tidak mudah dikuasai secara langsung oleh kekuasaan pemerintah, baik pemerintah pusat, daerah maupun di tingkat kabupaten mengharuskan ada cara-cara peralihan yang masih memerlukan rekomendasi dari Keraton. Banyaknya perangkat desa atau camat yang masih memiliki hubungan patron and client atau abdi-dalem. yang ditandai oleh sifat penguasaan atas tanah memang terkesan hubungan yang dipengaruhi oleh nilai-nilai feodalistik masih cukup relevan. Seberapa jauh instrument hukum dan UU Otonomi Daerah efektif dalam mempengaruhi perubahan masyarakat amat tergantung kepada upaya dari masyarakat, LSM, Lembaga Legislatif dan Eksekutif membuat kesepakatan bersama untuk dijadikan pedoman untuk dipatuhi dan dilaksanakan.

Karena itu, DPRD DIY tidaklah perlu ragu untuk memperjuangkan spirit demokrasi secara transparan sehingga Rancangan UU mengenai Daerah Istimewa Yogyakarta dapat dikeluarkan sesuai dengan upaya untuk mengakomodasikan berbagai nilai dan kepentingan sehingga disharmoni atau ketergangguan sosial bisa sedemikian rupa dapat dieliminir. Hanya saja bagaimana operasionalisasi dari proses perubahan itu secara sinergis mestinya mempertimbangkan, tidak saja eksistensi UUD 1945 dan peraturan lainnya, lebih utama dari itu, nilai-nilai (ewuh pakewuh dan hutang budi) dan normanorma (daulat Sultan) yang dianut masyarakat, baik dalam dimensi hak (istimewa), kewajiban dan kepuasan masyarakat DIY secara keseluruhan. Satu hal yang tidak bisa dilupakan, bahwa usaha untuk mengupayakan nilai demokrasi diterima secara utuh semestinya nilai-nilai demokrasi dan hukum menjadi pengetahuan lokal masyarakat Yogyakarta. 


\section{DAFTAR PUSTAKA}

Friedman. Lawrence, 1975, The Legal System: A Social Science Perspective, Russel Sage Foundation, New York.

Geofrey De Q and Walker, 1989, Initiative and Referendum: The People's Law, CIS Policy Monographs, The Centre for Independent Studies, New Soutwales..

Gerth, H.H. and Mills, Wright, 1977, From Max Weber: Essay in Sociol$o g y$, Routledge and Kegan Paul, London.

Huda, Ni'matul, 2000, "Beberapa Kendala Dalam Penyelesaian Status Hukum Bekas Swapraja di Daerah Istemewa Yogyakarta" Jurnal Hukum, No.13 Vol 7.

1997, Penyelenggaraan Koordinasi antara Pemerintah Daerah Tingkat I DIY dengan Keraton Yogyakarta dalam Pengaturan Pertanahan, Tesis Magister Humaniora, Program Pasca Sarjana UNPAD, Bandung.

Manan, Bagir, Perjalanan Historis Pasal 18 UUD 1945 (Perumusan dan Undang-Undang Pelaksanaannya), Unsika, Jakarta.

Poerwokoesoemo, Soedarisman, 1984, Daerah Istimewa Yogyakarta, Gadjah Mada University Press, Yogyakarta.

-,1979, Sejarah dan Monograpi Daerah Istimewa Yogyakarta, Gadjah Mada Press, Yogyakarta.

Rido, Ali, 1977, Badan Hukum Perseroan, Perkumpulan Koperasi, Yayasan Wakaf, Penerbit Alumni, Bandung.

Soemardjan, Selo, 1991, Perubahan Sosial di Yogyakarta, Gadjah Mada University Press, Yogyakarta.

Sujamto, 1988, Daerah Istimewa Dalam Era Kesatuan Republik Indonesia. Bina Aksara, Jakarta.

Thontowi, Jawahir, 2001, 'Penguasaan Tanah dan Pemilikan Tanah Yang Diskriminatif: Perspektif Hukum Internasional dan Hukum Nasional', JURNAL HUKUM, No $13 \mathrm{Vol} 7$

Timothy O'Hogan, 1984, The End of Law, Basil Blackwell, Oxford.

Watson, Alan, 1977, Society and Legal Change, Scotish Academic Press, Edinburg. 